\title{
Family influence on childhood excess weight in the Region of Murcia, Spain
}

\author{
María I. Jiménez Candel, B.S. ${ }^{a}$, Professor José Mondéjar Jiménez \\ Antonio J. Gómez Navarro, Graduate ${ }^{c}$ and Ana B. Monreal Tomás, Graduatec \\ Collaborator: Pedro J. Carpena Lucas, B.S. ${ }^{a}$
}

\begin{abstract}
Introduction. In Spain, childhood obesity is worrying, and its development might be influenced by the family setting. The objectives were to determine the prevalence of excess weight among adolescents, evaluate family variables that could affect it, and determine parents' body perception.
\end{abstract}

Population and methods. Cross-sectional study; students from five secondary schools in health area V of the Region of Murcia were included. Students' anthropometric measurements were recorded and a survey was administered to parents, including variables such as weight, height, exercise, level of education, family structure, and body perception. The analysis was done using contingency tables and the association with Somers' D measures.

Results. Four hundred and twenty one students participated (age: $12.8 \pm 0.6$ years old); $21.1 \%$ were overweight and $19.5 \%$, obese. There was an association between parent and child excess weight (Somers' $\mathrm{D}$ with a $p$ value $<0.05$ ). If both parents had a sedentary lifestyle, their children would exercise less. The higher the level of parental education, the lower the rate of childhood overweight $(p<0.05)$. Overweightobesity among children was higher in separated or single-parent families. In total, $32 \%$ of parents misperceived their children's excess weight and $53 \%$, their own.

Conclusions. In this sample, the prevalence of excess weight was $40.6 \%$. Parents' nutritional status, level of education, and family structure were associated with childhood obesity. Mothers had a greater influence on the development of their children's overweight. Parents underestimated obesity.

Keywords: adolescent, overweight, lifestyle, physical activity, family.

http: / / dx.doi.org/10.5546/ aap.2021.eng.99

To cite: Jiménez Candel MI, Mondéjar Jiménez J, Gómez Navarro AJ, Monreal Tomás AB. Family influence on childhood excess weight in the Region of Murcia, Spain. Arch Argent Pediatr 2021;119(2):99-105.

\section{INTRODUCTION}

In our country, childhood overweight and childhood obesity (CO) are up to $20 \%$ and over $10 \%$, respectively, and these figures are at the forefront of European countries..$^{1,2}$ Given its magnitude, the approach to childhood obesity and sedentary lifestyle is a public health priority in developed countries. ${ }^{1,3}$ Prevention strategies are mainly focused on decreasing morbidity and mortality in the adult age, improving quality of life, and diminishing health care expenditure. In Europe, at present, it is estimated that associated comorbidities account for a health care expenditure of about 10 billion euros yearly. ${ }^{4}$

Likewise, childhood and adolescence are the most vulnerable stages for weight gain, hence they are decisive in human development. An obese adolescent is up to five times more likely to be an obese adult, ${ }^{3}$ and the persistence of obesity in these generations could imply a shorter life expectancy than that of their parents. ${ }^{6}$ These periods entail multiple physiological, psychological, and behavioral changes, which, in turn, affect the development of healthy habits. ${ }^{7}$ A proper nutritional basis in childhood can prevent cardiovascular diseases, orthopedic, respiratory, metabolic, and inflammatory disorders, and even some types of cancer. $^{8}$

Obesity is a multifactorial problem in which genetic, metabolic, psychosocial, family, and environmental determinants are involved. ${ }^{9}$ The latter are becoming increasingly important as they have been, in part, responsible for the 
exponential increase of childhood obesity. This problem involves dietary changes deviating further and further away from the Mediterranean diet, a low level of physical activity (PA), increased screen time or reduced sleep time.

The family nucleus governs, from early stages, the adoption of habits that will have a direct impact on health. ${ }^{10,11}$ Hence the importance of determining the perception and involvement that parents have in their children's nutritional status and habits to avoid an obesogenic family environment. The presence of obesity in one of the parents doubles the risk of their children becoming obese and, in more than half of the children with obesity, one of their parents is obese. ${ }^{12}$ In addition, parents often overlook this problem and, according to national studies, up to $42.3 \%$ misperceive their children's weight status, ${ }^{13}$ leading to a higher probability for their children to be obese and a lack of involvement in solving the problem. Other research studies show that more than one third of parents are not interested in getting information on eating habits or do so inadequately. ${ }^{33,14}$

Given the problem and the likely influence of the family on their children's excess weight, the main objective was to determine overweight and obesity prevalence in a sample of adolescents and evaluate family variables that could affect them. The secondary objective was to establish parents' perception of their own and their children's weight.

\section{POPULATION AND METHODS}

Observational and cross-sectional study in which first-year secondary school students aged 12-14 years were included. Meetings were held with the directors of the seven health care centers of health area $V$ of the Region of Murcia to invite them to participate in the study. Four out of the seven accepted to collaborate (three public and one state-contracted facility) and two did not accept because of lack of time in the academic calendar. Taking into account the population of the area in that age range, a minimum sample size of 350 children was calculated for a maximum error of $4.92 \%$, with a $95 \%$ confidence interval. Participants were selected taking into account the proportionality in each health care center.

Parents were provided with information about the study, objectives, voluntary nature, anonymity, and confidentiality in accordance with Organic Law 15/1999 of December 13 on Protection of Personal Data, a brief survey, and an informed consent to be completed at home. In this survey, information was collected regarding family variables, such as parents' weight and height, practice of physical activity as per the recommendations of the World Health Organization, education level, family structure, and body perception. The exclusion criteria were having a severe chronic condition, an endocrine disease, an eating behavior disorder, or the parents' refusal to participate. The study was approved by the Clinical Research Ethics Committee of Hospital Universitario Virgen de la Arrixaca of Murcia.

The field work was carried out during the school years 2017-2018 and 2018-2019. A health team went to the centers to perform somatometric measurements on the participants once they had given their consent. Measurements were taken with students barefoot and in light clothing. Weight was measured with an approved Seca ${ }^{\circledR}$ scale and height was measured with the head adjusted to the Frankfurt plane perpendicular to the body with a portable approved stadiometer with a fixed base plate. All measurements were taken twice by the same observer, and the mean value was calculated. Once data were obtained, the body mass index was calculated. Values between +1 standard deviation (SD) and +2 SD were classified as overweight and values above $+2 \mathrm{SD}$, as obesity, according to the World Health Organization Z-score classification. ${ }^{15}$

The statistical analysis included a descriptive analysis and contingency tables, and, within the measures of association for ordinal data, Somers' D was used, based on the number of concordances and discordances in a data set, considering that the variables could be symmetric or dependent. A $p$ value $<0.05$ was regarded as significant. This analysis was conducted using the Statistical Package for the Social Sciences ${ }^{\circledR}$.

\section{RESULTS}

From an eligible sample of 567 participants, a total of 421 students, with a mean age of $12.8 \pm 0.62$ years, were recruited, of whom $52 \%$ were girls. The participation rate was $74.2 \%$. Five children were excluded due to chronic conditions (Turner's syndrome, hypothyroidism, trichorhinophalangeal syndrome, Maturity Onset Diabetes of the Young [MODY], and one student with reduced mobility), and $146 \mathrm{did}$ not participate because they did not give the informed consent. A total of $82 \%$ of the surveys were answered by mothers (Table 1). According 
to the somatometric measurements, the sample was divided into two groups: normal weight $(59.2 \%)$ and excess weight $(40.8 \%)$. Of the latter, $21.1 \%$ were overweight and $19.5 \%$, obese, with a slight predominance of males in the former and females in the latter. In addition, somatometric data were collected from $90.4 \%$ of fathers and $97 \%$ of mothers, $58 \%$ of whom had excess weight. The distribution by group can be seen in Figure 1.

The first variable studied by Somers' analysis was the influence of parental excess weight on their children's weight status. It was observed that $60.2 \%$ of mothers and $44.6 \%$ of fathers with excess weight had overweight or obese

TABle 1. Demographic characteristics of participants

Students n: 416. Fathers n: 376. Mothers n: 404.

Sex

Female: $216(52 \%)$

Male: $200(48 \%)$

Age

12 years old: $279(67 \%)$

13-14 years old: $137(33 \%)$

School

Public 395 (95\%)

State-funded private: $21(5 \%)$

Person filling in the questionnaire

Mother: $341(82 \%)$

Father: $62(14.9 \%)$

Both: $4(0.9 \%)$

Another caregiver: $9(2.2 \%)$

Family structure

Two-parent family: 320 (76.9\%) Single-parent family: 25 (6\%)

Separated: $60(14.5 \%)$ Other models: $11(2.6 \%)$

\section{Education level}

No education:

Primary education:

Secondary education:

Higher education:

Mothers

$14(3.3 \%)$

$169(40.6 \%)$

No data:

$137(33 \%)$

$95(22.9 \%)$

$1(0.2 \%)$
$169(40.6 \%)$

$145(35 \%)$

$66(15.9 \%)$

$16(3.8 \%)$ children, which showed a statistically significant relationship (Table 2). Figure 2 shows that the higher the number of overweight-obese members in a family, the greater the rate of children with excess weight.

As for the influence of family PA on the nutritional status of their children, a higher percentage of childhood excess weight was observed in families where both parents were sedentary compared to families where both parents exercised on a regular basis $(47.8 \%$ versus $34 \%$, respectively), although this difference was not statistically significant. A slightly lower figure was seen if it was the mother who exercised (Table 2). Also, in households where both parents exercised, the level of PA in their children was higher than in those where only one or none of the parents exercised (Figure 3). Likewise, there was a greater influence on a child being physically active if it was the mother who exercised (62.3\% versus $51 \%$ of fathers). Another of the variables studied was the family's active lifestyle (walking, cycling, etc.) and, among them, there was also a lower rate of overweight (38.8\%) compared to $53.4 \%$ in the rest of the families.

The third variable studied was the family structure. Most were two-parent families (Table 1). Overweight and obesity among children were higher in the group of separated or singleparent families (Table 2). Concerning the level of education of parents, it was observed that the higher the level, the lower the excess weight rate in their children, both significantly (Table 2).

Finally, in relation to parents' perception on their children's weight, $32 \%$ did not perceive their children had excess weight and believed that their weight was normal. Regarding their

FIGURE 1. Relationship between the nutritional status of participants and that of their parents according to the body mass index

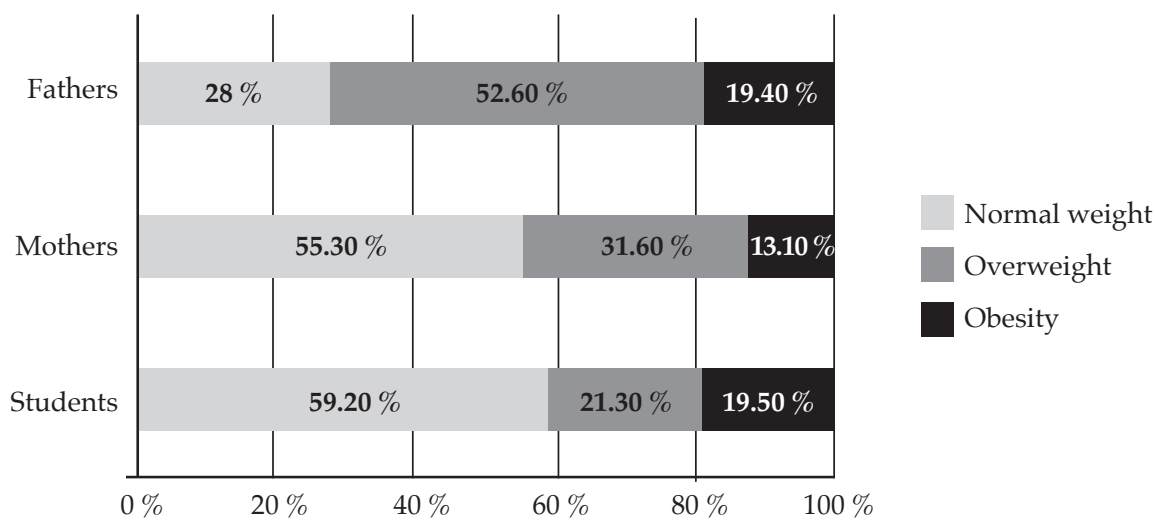


self-perception of their own weight, more than half of parents with overweight and obesity $(53.3 \%)$ believed their weight was normal, with fathers more likely to underestimate their weight than mothers $(60.2 \%$ and $43 \%)$. Up to $15.8 \%$ of obese parents believed that their weight was normal.

\section{DISCUSSION}

During recent decades, in our country there has been an exponential increase in the prevalence of childhood obesity. ${ }^{15,16}$ Figures detected are similar to those found in recent studies, such as the ALADINO study (23.2\% of children were obese and $18.1 \%$, overweight). ${ }^{17}$

TABLE 2. Influence of family variables on their children's overweight and obesity

Students n: 416. Fathers n: 376. Mothers n: 404.

Variable

Children with overweight or obesity

* $p$ value

Family excess weight

Mother:

$60.2 \%$

Father:

$44.6 \%$

$p<0.001$

Physical activity

Mother:

$39.6 \%$

Father:

$42.8 \%$

Father:

(1)

Education level

Mother

$51.7 \%$

No education:

$46.1 \%$

Primary education:

$38.2 \%$

Secondary education:

$32.6 \%$

Higher education:

$35 \%$
$49 \%$
$38 \%$
$32.6 \%$

No education:

Primary education:

Secondary education:

Higher education:

$32.6 \%$

Family structure

Two-parent family:

Separated:

$38.2 \%$

$50 \%$

$52 \%$

Single-parent family:

$45.4 \%$

Other:

$p=0.432$

$p=0.457$

$p=0.010$

$p=0.030$

$p=0.050$

$p=0.045$

* Somers' D.

FIGURE 2. Relationship between parents' and children's excess weight

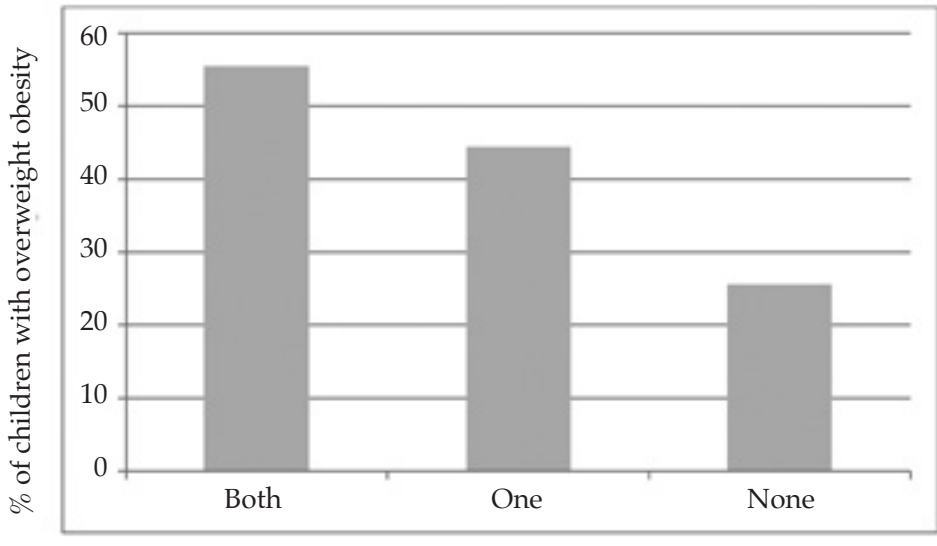

Number of parents with overweight or obesity 
Although several developed countries have recently reported stabilization in the prevalence of childhood obesity, in Spain and Portugal the trend seems to continue increasing. ${ }^{2,18}$ In the present study, obesity rates obtained were higher than in previous studies conducted in Murcia, such as the Four Provinces Study in $2000,{ }^{19}$ with a rate of $14 \%$, or that of Espín et al., in 2013 , with a rate of $18 \% .{ }^{20}$ Since there are multiple environmental variables intrinsic to each population, depending on the geographic characteristics, resources, socioeconomic level, habits and customs or the social environment and access to recreational areas, standardized, comparative studies should be conducted using objective somatometric measurements so as to be able to develop prevention and treatment strategies.

Most research studies conducted so far have related parental economic and academic levels to children's weight status, but it is important to take into account that parents' nutritional status, habits, family structure, and body perception play a critical role. In general, these variables are studied in a merely demographic way, and the influence they might have on health is overlooked.

A strong association between parents' and their children's weight was found, and childhood overweight was twice higher in families where both parents were overweight. This finding might be a consequence of the double genetic burden from two overweight or obese parents, or a result of common family environmental exposure of greater severity in promoting a family's unhealthy weight gain. ${ }^{21}$ This relationship was more pronounced in the case of mothers, likely affected by genetic, prenatal, and perinatal factors, such as being obese during pregnancy; these factors were already described, ${ }^{5,11,22}$ but not observed in this study. In today's society, most mothers are usually the primary caregivers and, consequently, have a greater influence on their children's habits.

In the present study, the practice of physical activity by parents conditioned that of their children's and influenced their weight status, more markedly when it was the mother who exercised less, although it was not statistically significant. Although described in other national studies, ${ }^{9,17,23}$ in our case, this association has not been observed possibly because of the sample size or type. Thus, behaviors, parenting styles, and lifestyles passed down from parents to children must be taken into account when addressing childhood excess weight. ${ }^{11,24,25}$ In fact, certain eating patterns, sedentary lifestyles, and other behavioral traits can be easily passed down from parents to children through the family socialization process. ${ }^{21}$

Due to globalization, eating habits have changed; diets based on fast and ultra-processed foods are now a new reality. ${ }^{13,26}$ So much so that, despite the characteristics that differentiate the regions of Spain, analyses show great similarity between all areas, due to the deterioration that has occurred in the so-called "Mediterranean diet" in recent years. ${ }^{27}$ This fact is shared by most other countries in Europe or the USA. ${ }^{28}$ The development of an obesogenic environment

FIGURE 3. Relationship between parents' and children's physical activity

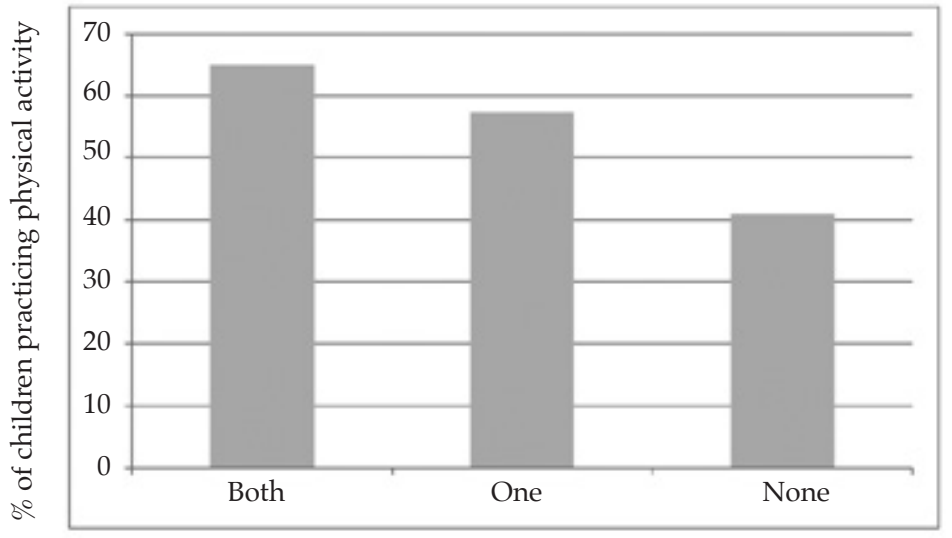

Number of parents practicing physical activity 
promotes an increase in energy consumption and a decrease in PA, without forgetting that Spanish parents practice less PA compared to those in other European countries and that most obese children have a poor physical fitness level. ${ }^{11}$

In this study, a higher rate of obesity was found in separated or single-parent families, possibly because of having fewer resources and less time available to establish healthy practices. Other authors have also determined how dysfunction in family dynamics can be a risk factor for the presence of child obesity. ${ }^{29,30}$ Some research studies show a greater number of family conflicts in families with obese children. These will, in turn, lead to additional stress, apart from promoting unhealthy environments contributing to the poor energy regulation capabilities of children. Likewise, family dysfunction predicts worse adherence to treatment, considering child obesity a chronic disease. ${ }^{31}$

Parents' education level was significantly associated with their children's nutritional status, probably due to the fact that the most qualified parents are better informed, more aware of the problem, and practice more PA. ${ }^{14,25,32}$ Conversely, a lower educational level or lower social classes appear to be risk factors for child obesity. ${ }^{11,14,17}$ All of this is conditioned by factors such as less purchasing power and greater limitations to practice sports activities or less access to fruit and vegetables.

Lastly, it is observed that, in general, there is a tendency to underestimate overweight and obesity, both one's own and one's children's, since more than one third of parents underestimated their children's weight problem. In studies such as ALADINO $^{17}$ with $50 \%$, Díez-Gañán ${ }^{33}$ with $55 \%$, and up to $60 \%$ in the periodic study by Salcedo et al., ${ }^{34}$ the number of parents who did not perceive their children's excess weight was even higher. Obesity is usually a slow and progressive condition; therefore, most of the times it is not a reason for consultation. Additionally, many times an overweight child is perceived as indicative of a healthy child. ${ }^{32}$ There is a problem of perception or tolerance of excess weight in which family and sociodemographic variables must be taken into account in order to address it.

Unlike other studies in which only the body image of adolescents is studied, the novelty of this study has been to include parents' selfperception, which is also confirmed as being wrong. In the light of these findings, it can be seen that there is a general underestimation of weight and that parents need to be aware of the problem so as to establish prevention and treatment strategies. There is evidence that, by including parents in programs to treat obesity, better results are obtained. ${ }^{5}$ Based on the above mentioned, it would be necessary to conduct longitudinal and multicenter studies to find out those parental factors that most condition the onset and perpetuation of childhood overweight.

The limitations of this study were the small sample size because participants were from a specific health area, and the collection of subjective data from parents' somatometric measurements, with a likely information bias. One of the strengths of the study was the objectivity of students' somatometric measurements.

\section{CONCLUSIONS}

In this sample, the prevalence of excess weight was $40.6 \%$. An association was detected between childhood obesity and parents' nutritional status, their level of education, and the family structure. Although mothers seem to have more influence on their children's weight status, childhood overweight was twice higher in families where both parents had excess weight. There is a serious problem of perception and tolerance to excess weight among parents.

\section{REFERENCES}

1. Nishida C, Uauy $R$, Kumanyika S, Shetty P. The joint WHO/FAO expert consultation on diet, nutrition and the prevention of chronic diseases: process, product and policy implications. Public Health Nutr. 2004; 7(1A):245-50.

2. Garrido-Miguel M, Cavero-Redondo I, Álvarez-Bueno C, Rodríguez-Artalejo F, et al. Prevalence and Trends of Overweight and Obesity in European Children from 1999 to 2016: A Systematic Review and Meta-Analysis. JAMA Pediatr. 2019; 173(10):e192430.

3. Simmonds M, Llewellyn A, Owen CG, Woolacott N. Predicting adult obesity from childhood obesity: Asystematic review and meta-analysis. Obes Rev. 2016; 17(2):95-107.

4. Müller-Riemenschneider F, Reinhold T, Berghöfer A, Willich SN. Health-economic burden of obesity in Europe. Eur J Epidemiol. 2008; 23(8):499-509.

5. Lurbe E, Redon P. Nuevos elementos en la obesidad infantil. Endocrinol Diabetes Nutr. 2019; 66(3):137-9.

6. Patrick H, Hennessy E, McSpadden K, Oh A. Parenting styles and practices in children's obesogenic behaviors: scientific gaps and future research directions. Child Obes. 2013; 9 (Suppl 1):S73-86.

7. González-Gross M, Castillo MJ, Moreno L, Nova E, et al. Alimentación y valoración del estado nutricional de los adolescentes españoles (Estudio AVENA). Evaluación de riesgos y propuesta de intervención. I. Descripción metodológica del proyecto. Nutr Hosp. 2003; 18(1):15-28.

8. Medrano MJ, Cerrato E, Boix R, Delgado-Rodríguez M. Factores de riesgo cardiovascular en la población española: metaanálisis de estudios transversales. Med Clin (Barc). 2005; 124(16):606-12. 
9. Yánez-Ortega JL, Arrieta-Cerdán E, Lozano-Alonso JE, Gil-Costa M, et al. Prevalencia de sobrepeso y obesidad infantil. Estudio de una cohorte en Castilla y León, España. Endocrinol Diabetes Nutr. 2019; 66(3):173-80.

10. Pérez-Ríos M, Santiago-Pérez MI, Leis R, Martínez A, et al. Exceso ponderal y obesidad abdominal en niños y adolescentes gallegos. An Pediatr (Barc). 2018; 89(5):302-8.

11. Miqueleiz E, Te Velde S, Regidor E, Van Lippevelde W, et al. Hábitos de vida y estilos de cuidado de los progenitores relacionados con la obesidad infantil. Comparación de una población española con poblaciones de países del Norte de Europa: ENERGY-Project. Rev Esp Salud Pública. 2015; 89(5):523-32.

12. MaggeSN, Goodman E, Armstrong SC, Daniels S, et al. The metabolic syndrome in children and adolescents: Shifting the focus to cardiometabolic risk factor clustering. Pediatrics. 2017; 140(2):e20171603.

13. Coronel Rodríguez C, González Zorzano E, Hernández A, Escolar Jurado M, et al. Encuesta epidemiológica sobre la percepción y hábitos desalud de las familias españolas sobre nutrición infantil. Pediatr Integral. 2017; 21(3):221.e1-12.

14. González Jiménez E, Aguilar Cordero MJ, García CJ, García LópezP, et al. Influencia del entorno familiar en el desarrollo del sobrepeso y la obesidad en una población de escolares de Granada (España). Nutr Hosp. 2012; 27(1):177-84.

15. De Onis M, Garza C, Onyango AW, Martorell R (eds.). WHO child growth standards. Acta Paediatr. 2006; 95(Suppl 450):5-101.

16. Toledano Marín, Aznar Lain S, Cortés Rico O, Ferreira Montero I, et al. 1.a Conferencia de Prevención y Promoción de la Salud en la Práctica Clínica en España. Prevención de la obesidad infantily juvenil. Madrid:Ministerio deSanidad y Consumo; 2007. [Accessed on: November $4^{\text {th }}, 2020$ ]. Available at: https:/ / www.mscbs.gob.es/profesionales/ saludPublica/prevPromocion/docs/PrevencionObesidad. pdf.

17. Ortega Anta R, López-Sobalñer A, Aparicio Vizuete A, González Rodríguez L, et al. Estudio ALADINO 2015: Estudio de Vigilancia del Crecimiento, Alimentación, Actividad Física, Desarrollo Infantil y Obesidad en España 2015. Madrid: Agencia Española de Consumo, Seguridad Alimentaria y Nutrición. Ministerio de Sanidad, Servicios Sociales e Igualdad; 2016. [Accessed on: October $25^{\text {th }}, 2020$ ]. Available at: https:/ / www.aesan.gob.es/AECOSAN/ docs / documentos / nutricion/observatorio/Estudio_ ALADINO_2015.pdf.

18. Rokholm B, Baker JL, Sørensen TI. The levelling off of the obesity epidemic since the year 1999 - a review of evidence and perspectives. Obes Rev. 2010; 11(12):835-46.

19. Garcés C, Lasunción MA, Ortega H, López Cubero L, et al. Factores metabólicos en la población escolar asociados a mortalidad cardiovascular en los adultos. Estudio Cuatro Provincias. Med Clin (Barc). 2002; 118(20):767-70.

20. Espín Ríos MI, Pérez Flores D, Sánchez Ruíz JF, Salmerón Martínez D. Prevalencia de obesidad infantil en la Región de Murcia, valorando distintas referencias para el índice de masa corporal. An Pediatr (Barc). 2013; 78(6):374-81.

21. Wang Y, Min J, Khuri J, Li M. A Systematic Examination of the Association between Parental and Child Obesity across Countries. Adv Nutr. 2017; 8(3):436-48.
22. Mora-Urda AI, Espinoza A, López-Ejeda N, Acevedo Cantero $\mathrm{P}$, et al. Indicadores de riesgo cardiovascular, patrones de lactancia y estilo de vida de la madre durante el proceso de crecimiento y desarrollo fetal e infantil. Nutr Clin Diet Hosp. 2015; 35(2):91-100.

23. Martínez-Villanueva J, González-Leal R, Argente J, MartosMorenoGÁ. La obesidad parental se asocia con la gravedad de la obesidad infantil y de sus comorbilidades. An Pediatr (Barc). 2019; 90(4):224-31.

24. Ariza C, Ortega-Rodríguez E, Sánchez-Martínez F, Valmayor S, et al. La prevención de la obesidad infantil desde una perspectiva comunitaria. Aten Primaria. 2015; 47(4):246-55.

25. Pérez-Rodrigo C, Gil Á, González-Gross M, Ortega RM, et al. Clustering of dietary patterns, lifestyles, and overweight among Spanish children and adolescents in the ANIBES study. Nutrients. 2015; 8(1):11.

26. Garcia-Continente $X$, Allué N, Pérez-Giménez A, Ariza $\mathrm{C}$, et al. Hábitos alimentarios, conductas sedentarias y sobrepeso y obesidad en adolescentes de Barcelona. An Pediatr (Barc). 2015; 83(1):3-10.

27. Chocarro Egüaras R. Hábitos alimentarios y comparación con las diferentes zonas españolas. Quinto Congreso de Economía de Navarra. [Accessed on: November $2^{\text {nd }}, 2020$ ]. Available at: http:/ / www.navarra.es/NR/rdonlyres / D82C4DCB-5DBC-401B-920E-58808A6DEEF7 / 79829/17 RAQUELCHOCARRO.pdf.

28. Liberali R, KupekE, Altenburg de Asis MA. Dietary Patterns and Childhood Obesity Risk: A Systematic Review. Child Obes. 2020; 16(2):70-85.

29. Moens E, Braet C, Bosmans G, Rosseel Y. Unfavourable family characteristics and their associations with childhood obesity: A cross-sectional study. Eur Eat Disord Rev. 2009; 17(4):315-23.

30. Sánchez-Martínez F, Torres Capcha P, Serral Cano G, Valmayor Safont $S$, et al. Factores asociados al sobrepeso y la obesidad en escolares de 8 a 9 años de Barcelona. Rev Esp Salud Pública. 2016; 90:e40027.

31. Warnick JL, Stromberg SE, Krietsch KM, Janicke DM. Family functioning mediates the relationship between child behavior problems and parent feeding practices in youth with overweight or obesity. Transl Behav Med. 2019; 9(3):431-9.

32. Leech RM, McNaughton SA, Timperio A. The clustering of diet, physical activity and sedentary behavior in children and adolescents: A review. Int J Behav Nutr Phys Act. 2014; 11:4.

33. Díez-Gañán L, Galán Labaca I, León Domiínguez CM, Zorrilla Torras B. Encuesta de Nutrición Infantil de la Comunidad de Madrid. Madrid: Consejería de Sanidad de la Comunidad y Madrid; 2008.

34. Salcedo V, Gutiérrez-Fisac JL, Guallar-Castillón P, Rodríguez-Artalejo F. Trends in overweight and misperceived overweight in Spain from 1987 to 2007. Int J Obes (Lond). 2010; 34(12):1759-65.

35. Jain A, Sherman SN, Chamberlin LA, Carter Y, et al. Why don't low-income mothers worry about their preschoolers being overweight? Pediatrics. 2001; 107(5):1138-46. 